\title{
How regions do work, and the work we do: a constructive critique of regions in political ecology
}

\author{
Gregory Simon ${ }^{1}$ \\ University of Colorado Denver, USA
}

\begin{abstract}
This intervention suggests the need to closely examine uncritical uses of 'regions' in both geographical research and resource management contexts. In particular, I argue that regions are frequently leveraged in a manner that is often indistinguishable from, and thus analytically similar to, other concepts connoting connections and relationships across space. The US Department of Agriculture's Conservation Reserve Program is briefly described to illuminate the process and implications of using simplistic and erroneous regional designations (configured around the $100^{\text {th }}$ Meridian) to inform resource management policy. I proffer several ways in which regions 'do work' analytically, discursively and materially, and argue that it is precisely the performative nature of regions that warrants its utility and sustained application in scholarly and policymaking environments. Finally, I suggest that the analytic toolkit possessed by political ecologists makes us uniquely equipped to assess, reconfigure, and employ regions and regional designations in our research; applications that will hopefully inform more accurate, nuanced and socially just policies.
\end{abstract}

Key words: $100^{\text {th }}$ Meridian, conservation reserve program, political ecology, regions, environmental management

\section{Résumé}

Cet article préconise d'examiner avec attention les utilisations du concept de région dépourvues de tout sens critique, à la fois en recherche géographique et dans les contextes de gestion de ressources environnementales. Plus particulièrement, je soutien que le concept de régions est souvent utilisé de tel manière qu'il est généralement impossible de le distinguer d'autres concepts connotant des connections et des relations à travers l'espace, et donc qu'il est analytiquement similaire à ces différents concepts. Le programme de mise en réserve des terres fragiles aux États Unis (Conservation Reserve Program) est brièvement décrit pour mettre en lumière les processus et les implications simplistes et erronées de l'utilisation de "régions » (relatives au $100^{\mathrm{eme}}$ méridien) dans le cadre de politiques de gestions de ressources environnementale. Je présente plusieurs cas pour lesquels le concept de région fonctionne effectivement, de manière analytique, discursive et matérielle, et je montre que c'est précisément la nature performative du concept de région qui justifie son utilité et son application dans les contextes académiques et politiques. Enfin, je soutiens que les outils analytiques à la disposition des écologues politiques nous permettent d'évaluer, de reconfigurer, et d'utiliser le concept de région dans nos recherche d'une manière unique, qui, je l'espère, facilitera l'émergence de décisions politiques plus précises, plus nuancées, et plus juste socialement.

Mots clés: $100^{\text {ieme }}$ méridien, conservation reserve program, écologie politique, régions, gestion environnementale

\section{Resumen}

En esta intervención se sugiere la necesidad de examinar de cerca el uso indiscriminado de 'regiones' tanto en contextos de investigación geográfica como de administración de recursos. En particular, en este ensayo se argumenta que el concepto de regiones es frecuentemente aprovechado de tal forma que es normalmente indistinguible de, y por tanto analíticamente similar a, otros conceptos que sugieren conexiones y relaciones a

\footnotetext{
${ }^{1}$ Dr Gregory Simon, Assistant Professor, University of Colorado Denver, Department of Geography and Environmental Sciences, P.O. Box 173364, Campus Box 172, Denver, CO 80217-3364, USA. Email: gregory.simon "at" ucdenver.edu. I would like to thank Colleen Hiner and Innisfree McKinnon for their valuable insights on this essay, and also for their effective organization of the Special Section. This is the ninth article in Colleen Hiner and Innisfree McKinnon (eds.) 2016. "(Re)considering regional political ecology?", Special Section of the Journal of Political Ecology 23: 115-203.
} 
través del espacio. Brevemente se describe al Programa de Conservación de Reservas del Departamento de Agricultura de Estados Unidos para iluminar el proceso e implicaciones de usar designaciones regionales simplistas y erróneas (configuradas alrededor del Meridiano 100) para informar la política de administración de recursos. Ofrezco varias formas en las que el concepto de regiones 'sí funciona' analíticamente, discursivamente y materialmente, y argumento que es precisamente la naturaleza interpretativa de regiones lo que amerita su utilidad y sostenida aplicación en ambientes académicos y de políticas públicas. Finalmente, sugiero que las herramientas analíticas poseídas por ecologistas políticos nos hacen particularmente calificados para evaluar, reconfigurar y emplear a las regiones y a las designaciones regionales en nuestras investigaciones; aplicaciones que esperamos que informen a políticas más precisas, matizadas, y socialmente justas.

Palabras clave: Meridiano 100, programa de conservación de reservas, ecología política, regiones, administración ambiental.

\section{A constructive critique of regions}

Regions exist in biophysical form as a set of material conditions containing similar soil types, climate conditions, vegetation, habitat or other environmental features. They also exist in an administrative sense through, for example, common institutional territories, political bodies, and government regulations. Furthermore, regions may be characterized by their socio-economic function, including the presence of shared or interdependent economic activities, modes of production, investment flows and labor pools. Regions may also be understood as having shared cultural characteristics and/or identities associated with a common set of languages, foods, religions, customs, histories, moral economies etc. Finally, and perhaps most crucially, regions operate in a rhetorical capacity as a discursive construct reflecting previously described regional attributes - a set of ideas that, in turn, actively shape material conditions.

For the purpose of this essay, and given this journal's focus on political ecology, the term region is framed as a designation characterizing an amalgamation of all these modalities. Political ecologists are integrative by nature, bringing together ecology, culture, political economy and politics as well as material and discursive analysis. As such, we tend to interrogate the intersection of each of the afore-mentioned region types. Subsequent critiques and recommendations in this essay are therefore premised on a political ecological framing of the region as a synthetic space that combines these diverse qualities.

Despite its status as a foundational geographical concept, geographers and others in both academic and public settings are prone to use the term "region" uncritically. Regional designations are often leveraged as convenient labels to describe geographic areas or to bound a set of social or biophysical processes. In many instances, however, these conditions may just as easily be characterized using other descriptors such as networks, social systems, ecosystems, landscapes, assemblages, or webs of interaction.

In the context of hydraulic fracturing, for example, the term 'network' may ostensibly hold equivalent explanatory power when describing an area comprised by shared natural gas marketplace interactions, financial transactions, institutions, and sector-induced biophysical changes. My recent attendance at a community meeting near Denver, Colorado illuminates this point. Here, a local representative described an area immediately north of Denver as "a region characterized by a network of diverse actors who share a profound interest in the future of the rapidly expanding natural gas sector." The notion that a "network of actors" characterizes a "region" raises questions about the ontology of the region, and network, in question. How are they different? And for the purpose of this essay, when does a region become the right concept to invoke? What unique work can it do for us analytically?

The problem, as I see it, is that the term region risks succumbing to opacity and hollowness; eventually becoming an analytically blunt and ineffectual concept that is indistinguishable, in its application, from other related and overlapping concepts. As it is, the term region contains conceptual cracks that threaten to compromise its salience. These include reified notions of regional fixity given the historically contingent and spatially oscillating nature of complex processes constituting regional designations (Pred 1984). Such concerns should compel geographers to give greater scrutiny to regions in order to increase their incisiveness and justify their value in scholarly and broader discursive and policy contexts. Applying a corrective lens is particularly appropriate for political ecologists who are, by trade, committed to understanding both the world 
around us and the world of our ideas. This article (indeed this entire Special Section) thus signals a reflexive disciplinary moment akin to those reassessing concepts such as 'local' (e.g., Brown and Purcell 2005; Purcell and Brown 2005; Neumann 2008) and 'neoliberalism' (e.g., Bakker 2010; Castree 2008; Heynen and Robbins 2005; McCarthy and Prudham 2004) among many others.

To be clear, the question is not whether regions hold analytic salience or utility. Many examples from multi-state watersheds to coastal flood inundation zones - show how the application of regional designations are useful for distinguishing one area from another based on unique social and/or biophysical qualities. Walker (2003), for example, notes the benefits of regional analysis as a coherent geographic framing and scalar mooring for political ecologists given the field's shift in analysis from third to first world settings. Indeed, the authors of this Section seem to agree that regions figure centrally into the work of political ecology in the context of understanding and responding to the complexity of modern agrarian capitalism (Galt 2016) or connecting divergent perspectives on the implications of local land use activities to broader economic, environmental and cultural structures of influence (Hiner 2016). Similarly, regions are posited as a useful scalar frame to examine key (yet spatially differentiated) conditions undergirding and influencing the tone and substance of resource extraction debates in different parts the US West (Jenkins 2016).

Still others suggest that the significance of regions does not end with their material attributes or institutional designations. Regions are also experienced, performed and mobilized by various parts of and members of society. Political ecologists may find it useful to understand how knowledge within civil society is developed, assembled and circulated within, and with respect to, regions (Cadieux 2016), or how social activists - such as those associated with the environmental justice movement - leverage regional problems, networks and allegiances to articulate and advance their political goals (London 2016). Moreover, regions present a useful scale and analytic space through which practices and strategies of care, coexistence and reciprocity can be examined and theorized (Larson 2016). These examples, as aptly noted by Walker (2016), all point to the clear and ongoing utility of regions - understood as a discursively produced and reproduced conceptual construct reflecting material meso-scale coherence -- within diverse areas of political ecological research.

The more constructive question, then, is when such a designation is appropriate. In order to distinguish regions from other competing concepts such as networks, assemblages and systems, and to avoid conceptual imprecision, I offer a framework that outlines when and why political ecologists and others should leverage regions when classifying land and life geographically.

\section{How regions do work (and the work we do)}

I argue here that regions are performative and capable of doing work analytically, discursively and materially; and that it is precisely this work that makes regions a valuable concept. This work occurs when the sum (region) is greater than its parts. That is, when the use of 'region' enhances and activates new meanings and characterizations, ultimately conveying something greater, deeper, and additional to the entities and relationships it contains. The following political ecological themes provide fertile ground for (a) effectively analyzing the construction and application of regions, (b) justifying their continued salience and disciplinary prominence, (c) critiquing and modifying preexisting yet ineffective and problematic regional classifications, and (d) illuminating the unique contributions of regions in comparison to other concepts connoting relationships across space.

\section{Post-structural critique of regions: unearthing buried epistemologies}

Political ecology has a long tradition of destabilizing normative accounts of social and ecological conditions, categories and connections. This entails highlighting the origins, maintenance, and implications of conventional and frequently unchallenged geographical explanations. Here, political ecologists understand that some ideas do regressive, unjust, and even violent work. Following Bruce Braun's (1997) formative intervention examining cultural constructions of Vancouver Island forests, and their influence on local 
resource management practices and Aboriginal communities (and the large body of literature that study has inspired), this aspect of political ecology may be understood as unearthing buried epistemologies.

With this intellectual orientation, political ecologists are well equipped to engage in post-structural critiques of regions; a critical engagement that should unfold simply because such designations already exist and already do work. These critiques aim to show that regional designations are more than simply benign cartographic renderings or apolitical interpretations of space. Rather, underlying geographical imaginaries actively structure discursive representations of regions that have, in certain historical moments, shaped policies that reinforce geographical stereotypes such as core-periphery, modern-backward, reliableundependable and contributor-dependent (Brenner 1998; Gregory 1998). Geographical imaginaries, and the discursive regional constructions they give rise to, inform real policies with material implications for large populations and individual livelihoods (Hiner 2016, Larsen 2016, for example). Political ecologists should leverage post-structural critique to unearth the social origins of regions and demonstrate the ongoing and potentially harmful (and beneficial) work they do.

\section{Normative assessment of regions: following chains of explanation}

Political ecology is, at its core, committed to exposing and articulating connections across multiple scales in order to understand complex socio-environmental conditions and changes. These may include relationships associated with multi-scale processes ranging from distinct trophic interactions and climate dynamics to shared resource dependencies and sector production activities. Following Blaikie and Brookfield's foundational work (1987), and the vast amount of literature produced in its wake, this dimension of political ecology may be referenced simply as following chains of explanation.

This aspect of political ecology should be leveraged to promote normative assessments of regions and to expose distinct and observable regions based on diverse social and/or environmental criteria. Here, the work of regions is measured by their ability to inform (a) regional designations that characterize something greater than what is immediately apparent to the untrained eye or a surface level assessment, and/or (b) a more clear, refined and nuanced understanding of regional designations by revealing opaque yet influential connections between peoples, places, processes and resources across space - characteristics that make the area bounding them an ontologically salient and analytically meaningful geographical designation (Galt 2016, Jenkins 2016, for example). This is to say, a space holding both internal commonality and/or external distinctiveness (Walker 2003). This may take the form of a partition exercise whereby increased geographical explanation is generated through the continued division of space, or an aggregative process where smaller spaces are combined to reveal a larger set of unique connections and processes (Gregory et al. 2009).

\section{Emancipatory assessments of regions: planting new seeds}

Another influential strand of political ecology involves moving analysis beyond critique and towards the pursuit of novel, underreported, and alternative management approaches. Here, we understand that new formulations and ideas do good work that can help chart more just and equitable sustainable development trajectories. This aspect of political ecology follows Robbins' (2005) clarion call to, on occasion, bury the hatchet (of critique) and engage in sowing seeds (of sanguinity) towards the establishment of new socioenvironmental pathways and futures. This aspect of political ecology may be understood as planting new seeds.

It is important that political ecologists continue to utilize this emancipatory dimension of our craft and commit to recommending progressive policy alternatives. These constructive engagements may indicate the benefits of particular regional designations and promote their expanded application. Emancipatory research may also generate suggestions for re-imagining and re-framing current spatial constructions (Castree et al. 2014). A commitment to participatory data collection, polyvocality, and the integration of diverse worldviews will produce information that can assist the generation of more equitable and just regional designations - designations that reflect the experiences of those who actually constitute (and are constituted by) signature regional activities and processes. Rather than try to refine and improve the work that regions do through more scientifically accurate measurements (see 'normative assessments', above) this idiographic approach 
endeavors to inform new regional designations by exposing alternative perspectives and imaginaries, which may in turn generate more socially and ecologically just and suitable outcomes for local populations (Cadieux 2016, London 2016, for example).

\section{3. (Non)arid regions, the $100^{\text {th }}$ meridian and the Conservation Reserve Program}

The work of regional designations and our ability to constructively assess (and modify) them is evident in the United States Department of Agriculture's Conservation Reserve Program (CRP). The CRP program's use of arid and non-arid regions raises questions about how such designations are constructed rhetorically, deployed in policy, and experienced materially. At issue here is the way the $100^{\text {th }}$ meridian has come to function as a dividing line connoting the discontinuity between these two apparently distinct climatic regions.

It is important to begin by emphasizing that the $100^{\text {th }}$ meridian is an artifact of a long history of ideas about people and environments in the U.S. West. Over the past 150 years it has represented the separation of old from new, gentle from rugged, civilization from frontier and tamed from lawless, to name a few (Simon 2011). In his influential book The Great Plains, historian Prescott Webb describes the transformative power of this regional division as pioneers, settlers, businesses, and governments moved through it. Webb notes how "practically every institution that was carried across [the meridian] was either broken and remade or else greatly altered" $(1931,8)$. Equally enduring has been the climatic significance of the boundary that John Wesley Powell famously recorded in his 1879 U.S. Geographical and Geological Survey. Today, the 100th meridian persists as a geographic placeholder for this zone of transition, marking the precise regional boundary between the non-arid east and arid west.

Despite grossly oversimplifying this complex transition, early regional classifications built around the $100^{\text {th }}$ meridian have ossified over time and have even come to inform influential government policy. The Conservation Reserve Program is an example of a policy that reifies this regional distinction. The CRP is one of many initiatives established in the 1985 Farm Bill and promotes long-term agricultural productivity through dedicated land conservation, by giving landowners rental payments and cost-share assistance in return for letting a certain portion of their land lie fallow and regenerate for up to 15 years. These activities establish wildlife habitat, enhance forest and wetland resources, improve air quality, reduce sedimentation in water bodies and reduce topsoil loss to erosion.

Of note here is that the CRP takes the $100^{\text {th }}$ meridian - a fuzzy, representational, and symbolic regional boundary - and treats it, through policy provisions, as if it were absolute, real, and pragmatic. And this process does not unfold without significant material consequences. Depending on what side of the 100th meridian (and by default, climatic region) farmers enrolled in the CRP program live, they face different restrictions on how to conduct conservation efforts and manage agricultural resources.

When CRP conservation periods expire, farmers begin a breakout phase and prepare their land for the next round of crop production. The breakout phase typically involves removing restorative ground cover and initiating intensive soil tillage procedures that remove weeds, aerate soils, and break down organic matter in order to prepare productive seed and root beds. CRP rules declare May 1 as the breakout date for landholders in the 'arid' region to the west of the 100th meridian, and July 1 for landholders in the 'non-arid' region to the east. The earlier breakout date for arid farmers is meant to help them retain soil moisture and prevent evaporation during the conversion process.

As a result of early breakouts, farmers in the so-called arid region experience a longer growing season and have the ability to cultivate early-season crop varieties. These conditions provide competitive advantages for western farmers, many of whom can look across their fields at neighboring landholders who must wait up to 2 months to remove their conservation land cover (despite occupying the same micro-climatic conditions). While this land conversion difference only has minor impacts on farmer activities, to focus on the severity of the consequences is to miss the larger point. What matters most here is that CRP policies are structured around the 100th meridian at all.

Conservation Reserve Program policies have taken the 100th meridian-a simplified representation of the not-so-simple gradient dividing the non-arid east from the arid west—and hardened it into a concrete and actively managed boundary where farmers follow different rules depending on what 'climatic region' they 
reside within. Under the CRP then, the 100th meridian has effectively transitioned from a socially constructed line, to a line actively constructing society (Simon 2011). This is the power, indeed the problem, of reifying regions (and their geographical interface) in natural resource policy. Two farmers separated by only a few hundred yards may find they have different production capabilities and market opportunities because CRP rules preemptively determine one property to be in an arid region and the other in a non-arid region.

\section{Conclusion}

The case of the CRP and the $100^{\text {th }}$ meridian shows how regional designations do work by reinforcing and maintaining simplified geographical categories that influence management practices. Here, regional designations extend historical and culturally imbued spatial classifications into the policy realm - a byproduct of society's need to understand the natural world and categorize its elements through the construction of ecological classifications and boundaries (Latour 1993; Scott 1998). These simplistic regional characterizations, in turn, inform conservation policies that impact actual land use practices and individual farmers.

The case of the CRP also reminds us why political ecologists should leverage our unique skills set to interrogate regions such as those that inform the CRP. Post-structural assessment will reveal the social origins of, and buried epistemologies behind, these designations in order to assess their erroneous premises and the potentially negative work they do. Normative assessment will follow chains of explanation to develop better metrics for characterizing and delineating climatic and hydrological regions. This might include more fine-grained analysis of precipitation and humidity levels alongside cross-scale assessments of water conveyance systems and availability; an approach supporting Oklahoma Representative Frank Lucas' suggestion to "scrap the 100th Meridian as a factor in defining what is arid for early break out" (U.S. Congress 1997). Meanwhile, emancipatory assessment can be leveraged to illuminate agricultural practices and market connections for individual farmers through the promotion of participatory data collection and counter mapping activities. This may generate information that stokes (a) community activism, participatory planning and public mapping activities, and ultimately (b) leads to the creation of regional designations that better represent the livelihood interests of farmers living astride the $100^{\text {th }}$ meridian.

More generally, political ecologists should continue to closely examine regions and identify the simplistic, clumsy, and imprecise ways in which they are developed analytically, employed politically, and rendered in policy. Rather than reproduce such inaccuracies in our own work, or allow faulty designations to go unquestioned, political ecologists should take an active role in reassessing regions and contributing to more accurate and socially just formulations. Indeed, 'the region' is a distinct and influential concept in our discipline, and as political ecologists we wield an analytic toolkit well equipped to steward its broad application in scholarly and policy contexts.

\section{References}

Bakker K. 2010. The limits of 'neoliberal natures': debating green neoliberalism. Progress in Human Geography 34(6): 715-735.

Blaikie P.M. and H.C. Brookfield. 1987. Land degradation and society. Methuen.

Braun B. 1997. Buried epistemologies: the politics of nature in (post)colonial British Columbia. Annals of the Association of American Geographers 87(1): 3-32.

Brown J. and M. Purcell. 2005. There's nothing inherent about scale: political ecology, the local trap, and the politics of development in the Brazilian Amazon. Geoforum 36: 607-624.

Cadieux, K.V. 2016. Possible moral ecologies, the function of everyday curation, and the experience of regions. Journal of Political Ecology 23: 134-146.

Castree N. 2008. Neoliberalising nature: the logics of deregulation and reregulation. Environment and Planning A 40(1): 131. 
Castree N., W.M. Adams, J. Barry, D. Brockington, B. Büscher, E. Corbera, D. Demeritt, R. Duffy, K. Neves, P. Newell, L. Pellizzoni, K. Rigby, P. Robbins, L. Robin14, D. Bird Rose, A. Ross, D. Schlosberg, S. Sörlin, P. West, M. Whitehead and B. Wynne. 2014. Changing the intellectual climate. Nature Climate Change 4: 763-768.

Galt, R.E. 2016. The relevance of Regional Political Ecology for agriculture and food systems. Journal of Political Ecology 23: 126-133.

Gregory D., Johnston R., Pratt G., Watts M.J., Whatmore, S. 2009 The dictionary of human geography. Hoboken, NJ: Wiley-Blackwell.

Heynen N. and P. Robbins. 2005. The neoliberalization of nature: governance, privatization, enclosure and valuation. Capitalism Nature Socialism 16(1): 5-8.

Hiner, C.C. 2016. "Chicken wars", water fights, and other contested ecologies along the rural-urban interface in California's Sierra Nevada foothills. Journal of Political Ecology 23: 167-181.

Jenkins, J. 2016. Contested terrain of extractive development in the American West: using a regional political ecology framework to understand scale, biocentric conservation values, and anthropocentric resource utility. Journal of Political Ecology 23: 182-196.

Larsen, S.C. 2016. Regions of care: a political ecology of reciprocal materialities. Journal of Political Ecology 23: 159-166.

Latour B. 1993. We have never been modern. Cambridge, MA: Harvard University Press.

London, J. 2016. Environmental Justice and Political Ecology converge in the other California. Journal of Political Ecology 23: 147-158.

McCarthy J. and S. Prudham. 2004. Neoliberal nature and the nature of neoliberalism. Geoforum 35: 275-283.

McKinnon, I. and C.C. Hiner. 2016. Does the region still have relevance? (Re)considering "regional" political ecology. Journal of Political Ecology 23:115-122.

Purcell M. and J. Brown. 2005. Against the local trap: scale and the study of environment and development. Progress in Development Studies. 5(4): 279-297.

Robbins, P. 2012. Political ecology: a critical introduction. Oxford: John Wiley.

Scott J.C. 1998. Seeing like a state: how certain schemes to improve the human condition have failed. New Haven: Yale University Press.

Simon, G.L. 2010. The 100th Meridian, ecological boundaries, and the problem of reification. Society and Natural Resources 24(1): 95-101.

U. S. Congress. 1997. 105th Cong. Letter from Congressman Frank Lucas to USDA Secretary Dan Glickman. 11 June.

Walker, P.A. 2003. Reconsidering 'regional' political ecologies: toward a political ecology of the rural American West. Progress in Human Geography 27(1):7-24.

Walker, P.A. 2016. On 'Reconsidering Regional Political Ecologies' 13 years on. Journal of Political Ecology 23:123-125.

Webb W.P. 1931. The Great Plains. Lincoln: University of Nebraska Press. 